\title{
A Linguagem Violentada E A MiMESE HUMANA NAS DEMOCRACIAS ESPETACULARES: INTERLOCUÇÓES COM GIORGIO AGAMBEN
}

\author{
Castor M. M. Bartolomé Ruiz ${ }^{1}$
}

Resumo: É urgente aprofundar as análises críticas da deriva espetacular das atuais democracias. Para contribuir com esse objetivo, no presente ensaio, analisam-se alguns aspectos das pesquisas de Agamben a respeito das democracias espetaculares. Em um segundo ponto, desenvolve-se uma análise acerca da linguagem, que, na origem da política, na Grécia antiga, propunha criar um novo modelo de poder fundamentado no convencimento da verdade, e como, posteriormente, essa linguagem deslizou-se para técnicas instrumentalizadoras da verdade, na política. Em um terceiro momento, apresentarem-se os nexos da mimese humana com a deriva espetacular da linguagem, nas democracias contemporâneas.

Palavras-Chave: Democracia espetacular. Violência da linguagem. Subjetividades massificadas. Mimese. G. Agamben.

\section{INTRODUÇÃo}

Vivemos tempos em que a política reduziu os limites de suas possibilidades ao dualismo democracia ou autoritarismo. Toda perspectiva dual encerra a complexidade em simplificaçóes que terminam, por sua vez, violentando as diferenças. No dualismo democracia ou autoritarismo, certamente a pergunta que resta por responder é: de qual democracia se fala? Ao se formular o conceito democracia em singular, dá-se aparência de uma

\footnotetext{
${ }^{1}$ Doutor em Filosofia, Professor Titular do Programa de Pós-Graduação em Filosofia da Universidade do Vale dos Sinos (UNISINOS), São Leopoldo, RS - Brasil. Coordenador da Cátedra Unesco-Unisinos de Direitos Humanos e Violência, Governo e Governança. Coordenador Grupo de Pesquisa CNPq Ética, biopolitica e alteridade. (D) https://orcid.org/0000-0002-6826-1560. E-mail: castorbartolome@ terra.com.br.
}

https://doi.org/10.1590/0101-3173.2021.v44n3.02.p19

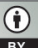

This is an open-access article distributed under the terms of the Creative Commons Attribution License. 
definição naturalista do que seja a democracia, como se houvesse um formato óbvio da democracia e só nos restaria seguir seus parâmetros. Longe disso, o dualismo democracia ou autoritarismo exige questionar e responder: qual democracia?

Das muitas possibilidades de abordagem dessa problemática, há que se atentar para a dinâmica dos atuais dispositivos de poder, que têm um nexo profundo com os modos de subjetivação. Cada vez mais, os modos de legitimação do poder, assim como o modus operandi dos seus dispositivos, dependem das formas de subjetivação: pois é pela captura colaborativa dos sujeitos que os dispositivos de poder obtêm o consentimento obediente das condutas, assim como a inserção produtiva dos indivíduos, ao mesmo tempo que validam sua legitimidade pela aquiescência cooperativa das maiorias. Os dispositivos de poder têm aperfeiçoado os métodos de intervir nas subjetividades humanas, a ponto de eles mesmos produzirem formas de subjetivação específicas que respondem às demandas estruturais do poder. Que essa lógica biopolítica ocorra nas democracias é um problema que afeta, inclusive, a própria existência das democracias. Porém, que as atuais democracias sejam responsáveis, omissas ou cúmplices, por produzirem modos de subjetivação massificados para conduzir docilmente a opiniâo das maiorias, a modo de decisóes pseudodemocráticas, é uma questão que transforma as democracias em demagogias e as desliza perigosamente para novas formas de autoritarismo.

Para analisar essa problemática, dividiremos nosso trabalho em quatro pontos. No primeiro ponto, analisaremos o que Agamben denominou democracias espetaculares, como desdobramento das sociedades de massas. Em um segundo ponto, apresentaremos uma reflexão, segundo Agamben, a respeito do deslocamento semântico da verdade, nas democracias modernas. No terceiro ponto, consideraremos os nexos entre as democracias espetaculares e o mimetismo humano. Concluiremos, esboçando algumas linhas possíveis de fuga aos modelos de controle massificado.

\section{A MASSIFICAÇÁo E AS DEMOCRACIAS ESPETACUlaRes}

Em suas pesquisas mais recentes, Agamben tentou responder a uma questão básica: se as democracias atuais estabeleceram seus rituais procedimentais para a legitimação do poder, por que o exercício do poder ainda necessita da glória? (AGAMBEN, 2007, p. 10). Se a glória é um dispositivo 
próprio das formas de soberania, por que o exercício democrático do poder continua a produzir formas de glorificação como meio para a legitimação do exercício do poder?

Essa questão levou Agamben a tentar conectar a temática dos modos de subjetivação das sociedades de massa com os novos dispositivos de glorificação das democracias contemporâneas (ROSS, 2006, p. 74-85). A glória e a glorificação são dispositivos teológicos que reconhecem, de forma sublime, a soberania absoluta de Deus. $\mathrm{O}$ poder soberano sempre quis associar o exercício do seu poder a diversas formas de glorificação, como meio de legitimação divina do exercício do poder (MURRAY; WHYTE, 2011). Esses dispositivos são pré-cristãos, pois uma maioria de reis e príncipes orientais se autoproclamaram descendentes dos deuses ou até a encarnação destes, como no Egito. Quando em Roma ocorre o declínio da República, os primeiros imperadores reclamaram para si o título divino de "augustos", para serem reconhecidos como deuses (AGAMBEN, 2007, p. 206). Todas as monarquias feudais e absolutistas dos séculos XVII e XVIII legitimaram seu poder como algo derivado diretamente de Deus. Esse contexto explica a proliferação das formas de glorificação política como dispositivos de legitimação do poder, assim como também explica a longa duração desses modelos de governo (ASSMANN, 2004, p. 1-11).

A liturgia é o modo como se processam as técnicas de glorificação. Se “[...] a função política essencial da glória, das aclamaçóes e das doxologias parece superada hoje" (AGAMBEN, 2007, p. 277), essa superação é só aparência, pois as liturgias não desapareceram, no exercício do poder atual. Muito pelo contrário, elas, em muitos casos, são condiçẫo necessária para conseguir a estabilidade do poder e até a sua própria legitimação. A questão que Agamben suscita é por que, nas atuais democracias, as formas de glorificação do poder não desapareceram, senão que se diversificaram em outros procedimentos? Por que essas técnicas de glorificação continuam a manter o objetivo histórico de ser uma sustentação necessária para o exercício do poder democrático?

Dentre as várias liturgias promovidas pelos novos dispositivos de glorificação, Agamben chama atenção particularmente para a técnica da aclamação. A aclamação já existia na Roma antiga, que, em muitos casos, tinha até valor jurídico, legitimando, ou não, um determinado governante ou general. "Sobretudo, a aclamação com que, na época republicana, as tropas outorgavam ao comandante vitorioso o título de imperator e, na época imperial, investiam-no com o título de César." (AGAMBEN, 2007, p. 190). Ela foi 
incorporada no cristianismo como técnica de glorificação divina, embora sempre continuasse a formar parte das liturgias de glorificação do poder político soberano, ao longo da Idade Média e nas monarquias absolutistas.

$\mathrm{Na}$ atualidade, a aclamação, enquanto técnica de glorificação do poder, não desapareceu soterrada pelos procedimentos formais do exercício democrático do poder, todavia, para além dos procedimentalismos, a aclamação continua vigente nas atuais democracias, sob a forma da opinião pública. Essa tese transparece ainda mais incisiva na análise que Agamben faz dos estudos de Carl Schmitt a respeito da importância da aclamação para o que esse autor denomina "democracias puras". Para Schmitt, "[...] a opinião pública é a forma moderna da aclamação” (SCMITT, 1938, p. 320), e o povo reunido, aclamando, representa o exercício mais direto e pleno da democracia, uma democracia pura. Sabemos historicamente como os governos fascistas e caudilhismos autoritários e populistas de todos os signos se utilizaram de múltiplos rituais de aclamação massiva, através dos quais consolidaram o poder do seu líder ou Führer.

Outrossim, Agamben leva a sério as implicações e desdobramentos atuais da tese de Schmitt de que "a opinião pública é a nova forma de aclamação". Se essa tese é verdadeira, assinala o autor, o problema a ser analisado diz respeito à função pública da mídia, na atualidade, uma vez que a opinião pública está, cada vez mais, atravessada pelas estratégias midiáticas que pretendem construíla, por meio da indução de opiniốes e comportamentos em escala massificada.

Para melhor compreender como é que a opinião pública se tornou uma forma moderna de aclamaçáo, Agamben recorre às análises de Guy Debord, o qual, em 1967, escreveu a obra $A$ sociedade do espetáculo (DEBORD, 1967). Segundo Debord, há uma transformação, em escala planetária, da economia e da política em um imenso espetáculo. A mercantilização capitalista transformou tudo em espetáculo e fez do espetáculo uma categoria epistêmica para a compreensão do mundo. Seria possível afirmar, com Debord, que, na atualidade, tudo que é real é espetacular. A partir dessa tese geral, Agambem propóe: "Se juntamos as análises de Debord com a tese schmittiana da opiniáo pública como forma moderna de aclamação, todo o problema do atual domínio espetacular da mídia sobre qualquer outro aspecto da vida social aparecerá numa nova dimensão." (AGAMBEN, 2007, p. 280).

A política atual e as democracias contemporâneas teriam se contaminado profundamente do modelo espetacular, a ponto de se tornarem 
"democracias espetaculares". Nas democracias espetaculares, o poder se legitima, principalmente, através de dispositivos de glorificação. As pesquisas de opinião pública, os índices de aprovação de um governo, os indicadores de popularidades, as enquetes de aceitação ou rejeição do governo, a imagem que prevalece de um governante etc. são novos dispositivos aclamatórios que sustentam ou até derrubam um governo, mostrando que ainda o poder (das atuais democracias) se sustenta na glória: "E como havia ocorrido nas liturgias profanas e eclesiásticas, esse suposto 'fenômeno democrático originário' é mais uma vez capturado, orientado e manipulado nas formas e segundo as estratégias do poder espetacular." (AGAMBEN, 2007, p. 280).

\section{A linguagem, A VERdAde E A DEMOCRACIA COMO PEITARQUiA}

Em um artigo publicado em 1970, na revista Nuovi Argomenti, intitulado "Sobre os limites da violência" (AGAMBEN, 1970, p. 154-174)2, Giorgio Agamben apresenta uma análise da estreita relação que vinculava a linguagem à democracia, na Grécia antiga, de sorte a esse modelo de democracias poder receber o epíteto de peitarquia, ou poder da persuasão, já que nelas a legitimidade do poder residia na capacidade de persuasão da linguagem. Os gregos das democracias originais estavam convictos de que a palavra tinha uma capacidade intrínseca de persuadir o outro, pela verdade inerente aos argumentos. Ou seja, a verdade tinha a capacidade de se impor como tal pelo mero exercício da linguagem, ao ser reconhecida como verdade, independentemente das formas retóricas ou argumentativas que a embrulhassem. Assim, a caracterização da política e a democracia como peitarquia advém da peculiar relação da verdade com a linguagem, da qual os gregos estavam convictos. "O atributo essencial da vida política se exprimia na sua caracterização como peitarquia, poder da persuasão: e esse poder era levado táo a sério que até mesmo o cidadão condenado à morte devia ser persuadido a matar-se com as próprias mãos.” (AGAMBEN, 1970, p. 160). A política era uma relação pública em que a verdade tinha um poder próprio de se impor como verdade, pela força inerente à linguagem. A verdade teria um

2 É conveniente registrar que, em fevereiro de 1970, mesmo ano em que Agamben escreve o artigo "Sobre os limites da violência", o autor se correspondeu com Hannah Arendt. Inclusive no final da carta, Agamben assevera que toma a liberdade de enviar um ensaio seu sobre a violência, o qual não poderia ter sido escrito sem o auxílio das obras de Arendt. Talvez, por essa proximidade cronológica, possamos inferir uma espécie de influência arendtiana nesse texto de Agamben, já que posteriormente o autor adotará posiçóes mais críticas e pessimistas a respeito das origens da política, na Grécia antiga, principalmente com o desenvolvimento do conceito de exceção inerente à política. 
poder intrínseco à sua condição de verdade, pelo qual ela poderia se mostrar como verdadeira, de forma necessária, no ato da linguagem.

Essa peculiar compreensão da verdade como poder intrínseco da linguagem era um atributo da própria verdade, e não dependia de técnicas persuasivas. As técnicas utilizadas pela linguagem para persuadir de uma verdade foram desenvolvidas posteriormente, e, nas origens das democracias gregas, não eram levadas em conta. A convicção a respeito da dimensão persuasiva da verdade fez da democracia grega, na sua origem, uma peitarquia, pois conferia à linguagem um poder, o qual, para os gregos, diferenciava a política do resto das outras formas de poder. As outras formas de poder se legitimavam pelo uso da força e do mais forte; a política grega troca a violência da força pela persuasão da verdade. $\mathrm{Na}$ origem da democracia, a linguagem neutraliza a violência na legitimação do poder. $^{3}$

Esse elo tão estreito entre linguagem e política (linguagem como forma pública de se relacionar) levou os gregos a denominar aneu logou (sem linguagem) todas as outras formas de vida que náo participavam da política. Os estrangeiros, os escravos, as mulheres, os trabalhadores e os artesãos não eupátridas, que estavam excluídos da ágora da polis, eram aneu logou, sem palavra. Certamente, com essa expressão, aneu logou, não queriam negar o fato de que todas essas pessoas tivessem a capacidade fisiológica da palavra e a linguagem, mas que, para os gregos, só na experiência política da democracia se realizava a dimensão mais sublime da linguagem, qual seja. a capacidade de persuadir pela verdade. Ser classificado como aneu logou equivalia "[...] à exclusão do único modo de vida em que somente a linguagem realmente tinha sentido." (AGAMBEN, 1970, p. 160). A linguagem adquiria seu pleno sentido no uso público da palavra, o qual se dava na argumentação política da verdade. Era na arena pública que a verdade brilhava como tal, ao ser reconhecida politicamente por todos. Os aneu logou eram também idiotai, pessoas privadas do poder público da linguagem.

O desenvolvimento das técnicas persuasivas em tempos posteriores deu lugar a vários ramos da linguagem, entre os quais a retórica e a oratória. Em ambas as técnicas argumentativas, a persuasão se impunha, não só pelo

3 Agamben, no ensaio "Introductory note on the concept of Democracy", analisa como, desde suas origens, há uma ambiguidade paradoxal no termo democracia, que contém em si mesmo dois significados diferentes: pode significar um princípio de soberania ou uma forma de governo - um significado jurídico-político e outro econômico-gerencial. Na democracia estaria presente a condição bipolar do poder moderno. (AGAMBEN, G. Introductory note on the concept of Democracy. In: ALLEN, A. (org.). Democracy in what state? New York: Columbia Unversity Press, 2011b. p. 1-5). 
valor intrínseco da verdade, mas principalmente pela forma com que era feita a argumentação dessa verdade e o modo como o orador expunha esses argumentos. Com o desenvolvimento das técnicas persuasivas da linguagem, a aceitação pública e política da verdade ficou refém das técnicas, e o valor intrínseco da verdade passou a ser considerado um aspecto secundário dessa verdade. Nesse caso, a validação política da verdade tornou-se dependente, em grande parte, das técnicas retóricas e argumentativas que a embasavam, e não do valor intrínseco da própria verdade. A partir de um determinado período das democracias gregas, o que convencia politicamente não era a verdade, mas o modo como essa verdade era apresentada. Este é um marco no qual a sofística, como técnica retórica e estilo de oratória, teve um amplo desenvolvimento. Através das técnicas da linguagem, poderia se expor, de forma convincente, qualquer tipo de verdade, para ser aceita na ágora pública.

Nas democracias gregas do século $\mathrm{V}$ a.C., as técnicas retóricas da linguagem tinham atingido um grande desenvolvimento e profusão. Havia uma alta influência dos sofistas, de seus métodos retóricos e da oratória. Nesse novo contexto das democracias, a persuasão das maiorias era feita, em muitos casos, pela maneira atrativa dos argumentos e pelas técnicas de oratória usadas para convencer os cidadãos. Essas técnicas, em muitas ocasióes, deslizaram as democracias gregas para formas de demagogia, pois as decisóes das maiorias eram induzidas por oradores e retóricos demagogos que se utilizaram das técnicas da linguagem para disfarçar a verdade.

Os filósofos se diferenciavam dos sofistas, porque ainda acreditavam que a verdade tinha um valor intrínseco, cuja validade se impunha por si mesma e náo poderia ser distorcida por falsos argumentos, sob pena de negar a própria verdade. O julgamento que levou à morte de Sócrates se mostrou como um evento paradigmático, no qual a democracia se deslizou finalmente para a demagogia, ao sacrificar o valor persuasivo da verdade às técnicas de persuasão. Nesse momento, muitos filósofos tomaram distância crítica daquele modelo demagógico da democracia grega. Por demais, era já o sinal histórico da decadência final a que foram levadas as experiências democráticas, nas polis gregas.

Agamben aponta que as democracias modernas nasceram com um diferencial qualitativo importante, em relação às democracias gregas. Estas surgiram pela convicção de que a verdade da linguagem tinha potencialidade de criar a política como espaço da persuasão e não da força, embora, no decorrer do tempo, assumiram que "[...] a verdade na política não é suficiente 
para persuadir diante da violência” (AGAMBEN, 1970, p. 161). Contudo, as democracias modernas introduziram na esfera da política uma outra forma de linguagem que nunca foi reconhecida como tal, na esfera pública da Antiguidade: a mentira. ${ }^{4}$ As democracias modernas teriam adotado, amplamente, a mentira como uma das técnicas persuasivas do próprio exercício argumentativo.

Ao empregar a mentira como técnica persuasiva, na política moderna, a linguagem abandona definitivamente a linha que separava a política da violência, convertendo a própria linguagem em uma forma de violência. Um exemplo que podemos considerar paradigmático dessa inversão violenta da linguagem na política constitui a invenção das campanhas de opinião pública. $\mathrm{Na}$ França, as primeiras campanhas de opinião pública foram idealizadas no governo de Richelieu, primeiro-ministro de Luiz XIV. Ele inventou o conceito de campanha política, através de panfletos e libelos, e concomitantemente "[...] inventou essa profissão de manipuladores da opinião, chamados naquela época de publicistas.” (FOUCAULT, 2008, p. 363).

O campo mais fértil da mentira como técnica persuasiva migrou, nas sociedades contemporâneas, da política para os modos de propaganda comercial. A propaganda e o marketing promovem a imagem de um produto que vale pela aparência, independentemente do conteúdo que tem. Ainda, segundo Agamben, a instrumentalização da linguagem em relação à verdade sofrera um outro deslocamento significativo, no século XVIII, na proliferação da chamada "literatura pornográfica". A partir do uso da pornografia como linguagem, um fenômeno absolutamente moderno, foi percebido que a linguagem tem um poder sobre os sujeitos afetados, o qual vai além dos argumentos, da retórica, da oratória ou de outras técnicas. Um poder que, inclusive, influencia os indivíduos sem o consentimento de sua vontade, excedendo sua própria racionalidade: "[...] determinadas expressóes linguísticas em um certo contexto podem produzir sobre quem as percebe um efeito que fica subtraído de sua vontade" (AGAMBEN, 1970, p. 162). A linguagem pornográfica revelou que há dimensóes da linguagem que têm o poder de influenciar a vontade dos indivíduos, mesmo que eles não queiram

${ }^{4}$ Nesse ponto, Agamben segue as teses de Arendt, a qual, no primeiro capítulo da obra Crises da República, afirma, a respeito da política moderna: "A veracidade nunca esteve entre as virtudes políticas, e mentiras sempre foram encaradas como instrumentos justificáveis nestes assuntos. Quem quer que reflita sobre estas questóes ficará surpreso pela pouca atenção que tem sido dada ao seu significado na nossa tradição de pensamento político e filosófico." (ARENDT, H. Crises da República. São Paulo: Perspectiva, 2010, p. 15). 
ser influenciados, pois a mera exposição a esse tipo de linguagem provoca neles emoçóes, sensações e sentimentos que irâo condicionar e até determinar seu comportamento, induzindo um tipo de vontade.

Uma das características da violência é que, "[ao] agir sobre o patrimônio instintivo do corpo humano, passa por acima da vontade e opera aquela redução do homem à natureza." (AGAMBEN, 1970, p. 162). Agamben indica que esse mecanismo é o mesmo da excitação erótica provocada pela linguagem pornográfica.

O Marquês de Sade representa o exemplo moderno de alguém que explorou a linguagem pornográfica como meio de produzir um tipo de violência provocada pelos efeitos não previstos e incontidos dessa linguagem. ${ }^{5}$ Essa "nova" virtualidade da linguagem provou que é possível utilizá-la como instrumento de convicção, independentemente das verdades, de seus argumentos, e inclusive além das retóricas ou oratórias, pois a linguagem consegue agir como elemento influenciador de condutas e indutor de comportamentos por estímulos incontrolados sobre os afetos e emoções. A política moderna muito cedo vai aderir a essa modalidade instrumental da linguagem, ao fazer dela um meio indutor de comportamentos. $\mathrm{O}$ modelo usado para influenciar os comportamentos, contornando a consciência crítica dos sujeitos, será a propaganda.

Com a propaganda, o poder da linguagem entrou num outro âmbito que era desconhecido da política grega, qual seja, o poder de influenciar a vontade dos sujeitos além de seu próprio consentimento. A propaganda se desenvolveu como um braço paralelo da mentira. Sem ser pura mentira, ela expóe uma verdade fragmentada, embrulhada em técnicas indutoras de emoçôes. Mas, principalmente, a propaganda atinge uma esfera da subjetividade em que o sujeito se sente induzido a crer algo pela mera sensação que o método produz nele, e náo pelos argumentos linguísticos do discurso. O princípio da propaganda é que uma verdade será aceita pela sua mera repetição, e não tanto pela sua argumentação. A propaganda, para impor uma verdade, limitase a um pequeno número de ideias repetidas incessantemente e apresentadas repetidas vezes, a partir de diferentes perspectivas, embora convergindo para o mesmo conceito. "Essa descoberta é o fundamento de uma forma de violência

\footnotetext{
${ }^{5}$ Não por acaso, uma personagem da obra de Sade, Filosofia na Alcova, Senhora de Saint-Age, afirma: "Amo loucamente a linguagem dessa gente amável! Entre nós, mulheres, também temos palavras exclusivas que provam, como essas, o profundo horror que sentimos por tudo o que não diz respeito ao culto admitido." (SADE, Marquês de. Filosofia na Alcova. São Paulo: Iluminuras, 2013, p. 14).
} 
amplamente difundida em nossa sociedade e que, pelo menos em sua atual estrutura, é a única que o nosso tempo pôde legitimamente pretender ter inventado: a propaganda." (AGAMBEN, 1970, p. 163).

A propaganda é a nova expressão do sofisma como técnica de linguagem, já que consegue a aceitação pública de uma verdade através do meio, independentemente do valor da verdade e seus argumentos. A linguagem da propaganda produz uma verdade que não se impóe pelos argumentos, nem mesmo pela bela retórica ou atraente oratória, mas pelas sensaçóes ou emoçóes que provoca nos sujeitos. A propaganda chega a usar a linguagem, esvaziando-a de sentido argumentativo, para preenchê-la de emoçóes. A emoção atinge os indivíduos em um âmbito pré-argumentativo, induzindoos a crer em verdades provocadas pelas emoçôes, mesmo que desprovidas de argumentos. Este é o campo em que o novo discurso político cresce.

Platão já tinha identificado uma dimensão emocional da linguagem na poética. Por esse motivo, fez severas críticas aos poetas, chegando a solicitar sua expulsão da cidade. Para Platão, o uso poético da linguagem desencadeia uma emoçáo que induz uma ação mimética, a qual extrapola a verdade dos argumentos. Por isso, Platão afirma: "O poeta deve renunciar à poesia como o amante que renuncia a uma paixão que não lhe faz bem.” (PLATÃO, 1950a, $\mathrm{X}, 60 \mathrm{e})$. Para o filósofo, a linguagem poética degrada a verdade e estimula uma ação mimética desprovida de argumentos verdadeiros e induzida pelo sentimento do agradável: "[...] o poeta imitativo introduz na alma de cada um regime miserável, agradando à parte irracional daquela." (PLATÃO, 1950a, 60e). Platão tinha percebido, na poesia, essa dimensão indutora de sentimentos que, contornando os argumentos da verdade, provoca condutas irracionais.

Na obra Politeia III, o autor faz uma classificação dos poetas em três estilos próprios. O primeiro é a narrativa simples (haplèdiēgèsis), que é representada pelo ditiritambo, na qual "[...] o próprio poeta é quem fala." (PLATÃO, 1950b, 392d10). O segundo estilo é a mimese representada na tragédia e na comédia, nas quais o poeta "[...] profere o discurso como se fosse outra pessoa." (PLATÃO, 1950b, 393c1). O terceiro estilo seria uma narrativa mista (diamphotéron), que é específica da poesia épica. Nesse estilo, o poeta faz uma mistura entre a narrativa simples e a mimese (PLATÃO, 1950b, 394c4).

Com efeito, Platão pensou nos efeitos nocivos para a política de uma linguagem que, contornando os argumentos da verdade, opera através 
da indução de emoçóes que provocam atitudes imitativas as quais estão privadas de um raciocínio específico. Naquele momento, Platão só identificou essa virtualidade emotiva da linguagem na poesia, por isso, pensou que o melhor era desterrar da polis tal tipo de linguagem, que poderia corromper a verdade da argumentação. ${ }^{6} \mathrm{O}$ que Platão não percebeu, na sua época, é que essa virtualidade emotiva da linguagem e indutora de comportamentos não racionalizados pelos sujeitos também poderia ser implementada por outros tipos de linguagem, como ocorre, nas sociedades atuais, com a propaganda.

A propaganda utiliza-se da linguagem para cometer uma espécie de violaçáo da vontade dos sujeitos, um novo tipo de violência que permite induzir o comportamento dos indivíduos, contornando a sua consciência crítica. "A manipulação das consciências através da violência linguística organizada se tornou uma experiência tão comum que uma exposição das relaçôes entre violência e linguagem é hoje parte integrante de uma teoria da violência." (AGAMBEN, 1970, p. 161). Na medida em que a política moderna emprega a propaganda como meio linguístico, desiste daquele princípio náo violento que estava na sua origem como nova forma de poder, a saber, que a linguagem, enquanto verdade, deve ser o meio do poder que substitui a violência.

Nesse ponto crítico, a utilização pública da linguagem como propaganda marca uma diferença qualitativa do uso da linguagem como persuasão, nas polis antigas. Se a política e a democracia originaram-se do uso da linguagem como meio de neutralizar a violência, no emprego atual da propaganda como técnica política e comercial, a violência retornou ao âmago da política e dos modos de subjetivação por meio da linguagem. No contexto desse escopo deve ser interpretada a afirmação de Agamben: "Os reinos da terra encaminhamse, um depois do outro, para um regime democrático-espetacular que constitui o acabamento da forma-Estado." (AGAMBEN, 2015, p. 81-82). Se toda violência carrega no seu seio o autoritarismo, a indução forçada dos comportamentos pelas técnicas propagandísticas levará, mais cedo ou tarde, a novos modelos de autoritarismo político.

Ainda que nas democracias sempre haja um campo de tensão para questionar essa realidade, os nexos entre propaganda e política não deixaram

\footnotetext{
${ }^{6}$ Remetemos aos estudos de Penelope Murray, a qual expóe que um dos objetivos da crítica de Platão a Homero seria a pretensão, de Platáo, de substituir a influência de Homero na educaçáo grega, colocando em seu lugar a filosofia e não a poesia. (MURRAY, P. (ed.). Plato on Poetry. New York; Melbourne: Cambridge University Press, 1966, p. 22).
} 
de aprofundar-se nas democracias modernas. ${ }^{7}$ As atuais formas da política utilizam-se dos subterfúgios mais sofisticados das propagandas midiáticas, para induzir a opinião dos cidadãos e produzir modos de comportamento previsíveis, adotando até modelos matemáticos e complexos cálculos algorítmicos que interagem com os comportamentos humanos: são os robôs digitais (BERRY, 2017). Os elos entre as motivaçôes incontroladas da vontade, que a pornografia moderna evidenciou, e a política midiática tornaram-se tão estreitos que a relação entre ambas (pornografia e política midiática) resulta muito mais que metafórica, no nosso momento histórico. Esses dispositivos investem em modos de subjetivação como técnicas políticas de sujeição dos comportamentos (MACGOVERN, 2011, p. 213-230).

A inversão pornográfica da linguagem na política atual atinge seu clímax no espetáculo. Tudo pode se tornar objeto de exibição, tudo é passível de ser uma realidade espetacular. Nessa deriva linguístico-política, a realidade só existe como espetáculo. Agamben, seguindo as teses de Debord, sustenta que o espetáculo opera uma exposiçáo que oculta. Os fatos exibidos como espetáculo suplantam a realidade, eles são a realidade. $\mathrm{Na}$ pretensão de realidade, o espetáculo camufla outras dimensóes, fatos e acontecimentos, os quais ficam ocultos através da invisibilização que o espetáculo promove sobre outras perspectivas. O espetáculo é uma especulação imaginária do real. Especula no amplo sentido do termo: o espetáculo transforma os objetos em mercadorias e transmuta a política em ficção encenada. "A forma extrema dessa expropriação do Comum é o espetáculo, isto é, a política na qual vivemos." (AGAMBEN, 2015, p. 79).

A sociedade espetacular que nos tornamos realiza-se pela inversão pornográfica da linguagem, a qual estimula as sensaçóes, ocultando as verdadeiras intençóes. $\mathrm{O}$ espetáculo realiza de maneira sofisticada a perversão violenta da linguagem, em que se solapam as verdades do diálogo para estimular emoçôes imprevistas. "A sociedade do espetáculo - se denominamos assim as democracias contemporâneas - é, desse ponto de vista, uma sociedade em que o poder em seu aspecto 'glorioso' se torna indiscernível com relação à oikonomia e o governo.” (AGAMBEN, 2007, p. 8). O espetáculo atinge o sujeito, através da inverdade da linguagem, a qual se torna uma verdade espetacular. A verdade espetacular é emoção produzida por sensaçóes programadas heteronomamente, que transformam o sujeito em espectador ou

7 Zarka também tece uma análise crítica a respeito de como as democracias modernas podem se transformar em demagogias midiáticas (ZARKA, Y. C. Figures du pouvoir. Études de philosophie politique de Machiavel à Foucault. Paris: Presses Universitaires de France, 2001, p. 117). 
consumidor de uma linguagem invertida (e violenta). "No espetáculo é a nossa natureza linguística que vem ao nosso encontro invertida." (AGAMBEN, 2015, p. 80).

A partir desse nexo sobre linguagem-violência-e-política exposto na reflexão de Agamben, cabe avançar na análise de mais uma questão: como os dispositivos biopolíticos conseguem induzir a massificação das condutas, através das técnicas espetaculares, respeitando os quesitos formais da liberdade humana? Como os indivíduos aceitam seguir docilmente as tendências comportamentais massificadas em um ambiente de tanta "liberdade" informativa? Perguntamos como, pois, nas técnicas de indução massificadora, o porquê permanece imperceptível para os sujeitos que se assujeitam, uma vez que eles decidem "livremente" aderir aos reclamos da propaganda. Para ampliar a compreensão crítica dos modos se assujeitamento massificado, propomos analisar a dimensão da mimese humana, como ela se relaciona com a linguagem e como opera nos dispositivos de massificação das democracias espetaculares.

\section{A Mimese, o ASSUjeitaMENTo E O ESPETÁculo}

A mimese é uma dimensão paradoxal da condição humana. $\mathrm{O}$ paradoxo da mimese opera tanto na forma de imitação emuladora como na de criação imitativa. A mimese é constitutiva da ação humana e pode desenvolver-se de múltiplas formas, por isso, ao longo da história do pensamento filosófico, encontramos posições e valorações diferentes e até divergentes em relação a ela (GEBAUER; WULF, 2004, p. 50). Neste ponto, vamos ponderar duas posiçôes críticas da mimese, Platão e Adorno, registrando que há outras perspectivas positivas sobre a mimese, como a de Aristóteles ou Benjamin, os quais percebem a mimese como uma potencialidade criativa do ser humano (RUIZ, 2016).

Como analisamos anteriormente, Platão foi o pensador que estabeleceu uma desconfiança da mimese humana e suas estreitas conexôes com a linguagem irracional dos poetas. Além disso, para Platão, a mimese é uma ação imitativa que rebaixa ontologicamente a ideia. Conforme esse filósofo, o mundo nada mais é que a imitação da ideia que há em Deus e que foi produzida (poiese) por imitação do original, que é ideal. Platão critica os sofistas, porque são os mestres da mimese. Ao instrumentalizar a linguagem, são capazes de apresentar uma "imitação" da realidade, no lugar da própria realidade (mimémata kai 
omónyma tòn ónton) (PLATÃO, 1950c, 234b). Eles têm a capacidade de deturpar a verdade e dar às coisas a aparência de verdadeiras, sendo falsas, porque empregam os artifícios miméticos na linguagem (PLATÃO, 1950b, 235 a-b). Platão censura os sofistas, principalmente, por produzirem um tipo de poiese que nada mais é que uma mimese que rebaixa o valor da verdade na linguagem.

Platão é um grande crítico da mimese, entendendo que esta, ao rebaixar o real à pura imitação, produz uma decadência na vida da polis (GAGNEBIN, 1993, p. 68). A mimese provoca uma diminuição da racionalidade e obstrui a criação de leis boas para a cidade. Segundo Platão, a mimese pode ser considerada um vício que anula a razão e sua capacidade criativa, pois induz a ilusão para confundir as imitaçôes com a realidade. Por isso, ela deve ser desterrada, no possível, da cidade.

Para Platão, a arte nada mais é que uma mimese do real, por isso, entende que a obra do artista é só imitação em segundo grau. Se a realidade é uma imitação da ideia, a obra do artista é uma imitação da imitação. $\mathrm{Na}$ obra de arte, a realidade é degradada duplamente pela mimese. No livro X de $A$ República, Platão propóe a comparação entre a poiese mimética de um marceneiro que faz uma cama imitando a ideia que ele tem a respeito, e o pintor que imita a cama pela pintura. A pintura é uma segunda imitaçáo do real, que é a ideia. "Por este motivo não devemos permitir a entrada da arte na cidade com boas leis, porque desperta e alimenta o vício e, fortalecendo-o destrói o princípio do racional." (PLATÃO, 1950a, 605a-606d).

Platáo percebe a influência da mimese na política. Na sua obra $A$ República, o autor analisa pormenorizadamente essas implicaçóes. Para ele, a ação política segue os princípios da verdade e não da doxa. A verdade sempre é uma, as opinióes são muitas. Por isso, o governo da cidade deve ser responsabilidade de quem conhece a verdadeira forma de conduzir a política e não se guia por opiniōes variadas. De acordo com Platâo, a arte é mera imitação do real e a retórica nada mais é que uma linguagem mimética, a qual disfarça o real sob a maquiagem de uma linguagem retórica enganosa. Os poetas são os mestres da mimese da linguagem, por isso, Platão considera que sua presença é perniciosa para a polis. O poeta, para Platão, é semelhante ao amante que se deixa levar pelos impulsos da paixão, e não da razão (PLATÃO, 1950a, 60e). O pernicioso dos poetas é que eles espalham essa forma mimética de linguagem na polis, estimulando um modo de verdade produzida por emoçóes e sentimentos e não pelos argumentos da razão. Em geral, a mimese deve ser 
afastada da polis, porque, sendo eivada por um tipo de linguagem emocional, degrada o conhecimento do político. De outro lado, Platáo considera que o filósofo é importante para a política, porque consegue ter um conhecimento da verdade além das meras mimeses. Isso o habilita para o bom governo da polis.

Que Platão tenha feito sua crítica à democracia ateniense, através do viés mimético da linguagem sofística, é um indício de como esse autor percebeu algumas das instrumentalizaçóes, as quais, já desde o século $\mathrm{V}$ a.C., se fizeram entre a linguagem e a mimese, e que conduziram em seu tempo à degradação da democracia.

Uma outra perspectiva importante para compreender a instrumentalização da mimese humana pelo poder político contemporâneo está presente nas análises que Adorno e Horkheimer fizeram a respeito, nos tempos de barbárie que lhes tocou viver. Esses autores, para tentar compreender a adesão das massas populares às experiências dos fascismos e do nazismo, voltaram seu olhar para a instrumentalização da mimese promovida por esses regimes (TIBURI, 1995). Para os autores, não seria possível entender a consolidação dessas formas autoritárias fascistas e o totalitarismo implantado pelo nazismo, sem uma análise de como esses regimes exploraram a capacidade mimética, a fim de assimilar as maiorias a um silêncio consentido pela produção de identidades fechadas.

No estudo que esses autores realizam sobre a Odisseia, na sua obra $A$ dialética do esclarecimento (ADORNO; HORKHEIMER, 2006, p. 47-70), assumem uma posição crítica a respeito da mimese, semelhante em muitos aspectos à postura de Platão. Os autores retomam as pesquisas de Freud e de certos etnólogos, como Mauss, em que a mimese humana é mostrada como uma atitude das pessoas que imitam o real de forma passiva (FRÜCHTL, 1986).

Nas palavras de Hubert e Mauss: "O uno é o todo, tudo está no uno, a natureza triunfa sobre a natureza." (MAUSS, 1902-3, p. 100). Adorno e Horkheimer prestam especial atenção às pesquisas de Caillois sobre o mimetismo. Conforme Caillois, o mimetismo humano é, também, um reflexo do mimetismo animal (CAILLOIS, 2002). O animal, quando se encontra em perigo, desenvolve uma atitude mimética que o identifica com o meio em que se encontra para, através da identificação mimética, confundir-se, passar desapercebido e não ser identificado. Nesse caso, o mimetismo é associado à 
camuflagem para escapar dos perigos. As pessoas também se utilizariam desse subterfúgio da identificação mimética, a fim de, em situações de perigo social, provocar formas de identificação com o meio social no qual se encontram e não serem identificadas como diferentes.

Ao mimetizar-se, os indivíduos querem perder os rasgos de singularidade que os exporiam como diferentes ao meio em que se encontram. A camuflagem mimética provoca nos indivíduos a adesão a uma identificação unitária, para evitar o perigo de serem diferentes. Nessa perspectiva, para Adorno e Horkheimer, o mimetismo, diluindo as singularidades, reforça as identidades sólidas e unitárias. "A assimilação física da natureza é substituída pela 'recognição no conceito', a compreensão do diverso sob o mesmo, o idêntico." (ADORNO; HORKHEIMER, 2006, p. 149). O mimetismo dissolve as diferenças numa totalidade unitária que produz a tendência social para um tipo de totalitarismo. Todo totalitarismo demandaria um processo de absorção das diferenças, numa espécie de totalidade idêntica, na qual todos os sujeitos se projetam como iguais no apagamento das diferenças. Estas ficam camufladas mimeticamente, de sorte a evitar os perigos dos destaques singulares.

De acordo com Adorno e Horkheimer, o medo é o fator determinante da mimese: "O corpo é paralisado pelo ferimento físico, o espírito pelo medo. $\mathrm{Na}$ origem, as duas coisas são inseparáveis." (ADORNO; HORKHEIMER, 2006, p. 210). A atitude mimética é desencadeada pelo medo social, que leva os indivíduos a camuflar suas diferenças para serem aceitos através da absorção numa identidade igual, que se transforma numa espécie de identidade total. Este será um dos paradoxos da cultura iluminista, a qual pretendeu emancipar os homens do medo e provocou novas formas identitárias de submissáo:

O medo que o bom filho da civilizaçáo moderna tem de afastar-se dos fatos - fatos esses que, no entanto, já estão pré-moldados como clichês na própria percepção pelas usanças dominantes na ciência, nos negócios e na política - é exatamente o mesmo medo do desvio social. (ADORNO; HORKHEIMER, 2006, p. 13).

De um lado, os autores destacam a atitude de Ulisses como paradigma de um modelo instrumental da razão, que, na sua sagacidade, soube instrumentalizar a mimese para dominar. Esta seria uma das chaves da dominação contemporânea das massas, a qual usou a mimese humana como um elemento da dominação. "A ratio que recalca a mimese, não é 
simplesmente seu contrário. Ela própria é mimese: a mimese do que está morto.” (ADORNO; HORKHEIMER, 2006, p. 45). A dominação e sua contrapartida, o medo, gerenciam a mimese como ferramenta para conseguirem a assimilação voluntária dos indivíduos aos reclamos da totalidade. A astúcia da razão opera utilitariamente a mimese humana como meio para obter a adesão consentida dos indivíduos aos modelos identitários da totalidade que tudo governa. As identidades absolutas privilegiam o conceito do autêntico, considerando a autenticidade a expressão máxima da identidade: "Aquilo que se recusa a definhar prefere acolher o estigma do não autêntico; vive da herança mimética. O humano adere à imitação: o homem somente se torna homem ao imitar os outros homens." (ADORNO; HORKHEIMER, 2008, p. 151).

Entendemos que as análises desses autores sobre a utilizaçáo da mimese como técnica política de submissão "voluntária" não devem se restringir aos regimes fascistas e nazistas, que eles priorizam em seus estudos. A questáo que propomos elucidar, neste ensaio, diz respeito às instrumentalizaçóes da dimensão mimética no contexto das atuais democracias. Embora o contexto de autoritarismo seja diferente dos governos fascistas, há um elo comum no emprego da linguagem mimética para induzir o comportamento massificado dos indivíduos. Esse nexo aparece explícito na propaganda. Adorno e Horkheimer, no capítulo de "Notas e esboços" da Dialética do Esclarecimento, dedicam um verbete à propaganda, afirmando: "A propaganda faz da linguagem um instrumento, uma alavanca, uma máquina." (ADORNO; HORKHEIMER, 2006, p. 209). A propaganda legitima o modo de ser das pessoas, produzido pela injustiça social, como se fosse algo naturalizado.

Os autores ressaltam que a propaganda conta com o fato de que se pode instrumentalizar as pessoas (MULLEN, 2016). Estas, por sua vez, no fundo, sabem que serão um meio para outro meio (a propaganda). A propaganda tem como escopo de si mesma a manipulação das pessoas e, "[...] onde grita liberdade, se contradiz a si mesma." (ADORNO; HORKHEIMER, 2006, p. 209). A propaganda, segundo os autores, reúne a todos numa espécie de "comunidade da mentira", pois a falsidade é inseparável dela. A verdade torna-se um meio para conquistar adeptos, a ponto de falsificá-la, quando é feita propaganda. A propaganda é inimiga das pessoas. Ela falsifica a política, tergiversando o princípio de que esta deve ser o resultado do discernimento comum. A verdadeira resistência não conhece propaganda. Nas sociedades de consumo, deve desconfiar-se de tudo que é recomendado. A culminação da linguagem publicitária encontra-se na indústria cultural, a qual, por sua 
vez, ela mesma é produzida pela propaganda em grande escala: "A indústria cultural está ajustada à regressão mimética, à manipulação de impulsos de imitação reprimidos." (ADORNO; HORKHEIMER, 2008, p. 197). A indústria cultural é o resultado mais elaborado do uso de linguagem como propaganda.

De acordo com Adorno e Horkheimer, a propaganda comercial deu um passo à frente e conseguiu tecer o nexo das artimanhas da sua linguagem enganosa com a política. A cumplicidade da fusão do mundo dos negócios com a política está explícita na publicidade. A propaganda da liberdade serve por igual para o consumo e para a política. "O é suspeito não é a representação da realidade como um inferno, mas a exortação rotineira a fugir dela.” (ADORNO; HORKHEIMER, 2006, p. 210).

A linguagem criou, na Grécia antiga, a política como espaço de veridição em que a verdade imperava como antídoto contra a violência, porém, a contaminação mimética introduziu o germe da violência nas formas de linguagem agenciadas pelos dispositivos de poder. A consequência disso é que o comportamento social e político moderno está amplamente induzido por enunciados de linguagem que os indivíduos repetem, a modo de comportamento singular, enquanto reproduzem mimeticamente performatividades discursivas agenciadas. ${ }^{8}$

Há uma sintonia muito próxima entre as análises de Adorno e Horkheimer sobre indústria cultural e os estudos sobre a democracia espetacular de Agamben. Ambas as análises se entrecruzam na crítica aos atuais procedimentos políticos das democracias formais que produzem a massificação como meio de dominação. A democracia espetacular produz tanto as identidades maciças quanto a dissolução das identidades em tendências comportamentais: "[...] a sociedade do espetáculo é, também, aquela na qual todas as identidades sociais se dissolveram." (AGAMBEN, 2015, p. 84). As críticas feitas às democracias de massas como democracias espetaculares não significam uma negação da democracia como regime de governo, senão que espelham uma fotografia crítica do presente das atuais democracias, as quais, no seu viés espetacular, estão sendo conduzidas para formas grotescas de demagogia. A redução da política a espetáculo não pode derivar na negação da

\footnotetext{
${ }^{8}$ Neste ponto, remetemos aos estudos de Deleuze e Guattari (2011, p. 65-66), em que os agenciamentos nomeiam comportamentos miméticos que os indivíduos realizam, como se fossem decisóes pessoais, e a linguagem contaminada pelos agenciamentos reproduz mimeticamente discursos produzidos com tal finalidade.
} 
política, mas na desconstrução do seu modelo espetacular. Esse posicionamento está nas antípodas de novos grupos e movimentos ultraconservadores e neofascistas que se aproveitam do desencanto generalizado provocado pelo vazio político das democracias espetaculares, para oferecer velhas alternativas autoritárias recicladas com roupagens xenófobas, nacionalistas e populistas.

\section{ConsideraçóEs Finais}

Ao longo do ensaio, quisemos interrogar sobre como, nas atuais democracias espetaculares, operam os dispositivos de sujeição voluntária, pervertendo o sentido originário da política (e como consequência da própria democracia), instrumentalizando a relação da linguagem com a política. Ao relacionar os estudos de Agamben sobre a linguagem e a política com as algumas análises da mimese, é possível elucidar várias conclusôes.

A propaganda é a tecnologia moderna que desencadeou a inversão pornográfica da linguagem, a qual, contornando a consciência crítica dos sujeitos, consegue provocar emoçóes, sensaçôes e comportamentos sobre os quais os sujeitos nem sempre têm pleno controle. Entre outras várias técnicas, os dispositivos biopolíticos de controle têm utilizado, de modo instrumental, o potencial mimético humano associado à tecnologia da propaganda, a fim de tentar gerenciar as condutas dos indivíduos, já que essa associação produz fortes estímulos, com uma baixa consciência crítica das motivaçóes.

A mimese é uma dimensão do comportamento humano que tem diversas funçôes na existência humana. Ela, associada à propaganda, é amplamente instrumentalizada em várias dimensôes da sociedade de massas (divertimento, consumo, segurança, negócios, comportamentos urbanos, espetáculos, modas, comunicaçôes etc.); resulta até difícil pensar uma área da existência humana que não esteja colonizada por essa tecnologia. $\mathrm{O}$ nexo instrumental entre mimese e propaganda reconfigurou as potencialidades de estímulos primários sobre os indivíduos, aumentando o poder desse tipo de linguagem sobre seu condicionamento comportamental.

Essa inversão pornográfica da linguagem oculta as verdadeiras intençôes dos proponentes, impondo concomitantemente um novo tipo de sofisma que leva os indivíduos a assumirem uma convicção, estimulados por mensagens das quais não conseguem perceber as intençóes não explicitadas nelas. Nesse modo de linguagem propagandístico habita uma violência que 
atua através da violação da liberdade do sujeito, já que consegue assujeitar as vontades, induzindo determinados comportamentos e produzindo um tipo de adesão pouco "consciente" a uma motivação desconhecida. Esse paradoxo da mimese propagandística produz uma liberdade induzida, a qual assimila o comportamento dos indivíduos às tendências traçadas pelos estrategistas dos comportamentos de massas.

A utilização explícita e massiva dos meios propagandísticos pela política atual transformou a política num contraponto do que foi a política originária. Se a origem da política remete à possibilidade do uso da linguagem para substituir a violência nas relaçôes de poder, a política atual instrumentaliza a linguagem, inserindo a violência no modo estratégico de induzir os comportamentos. Essa indução comportamental náo poderia ser feita por meio do diálogo persuasivo que expóe abertamente a verdade das intençóes dos sujeitos, que era a característica da linguagem política originária. Por isso, a política atual adota, de forma profusa e , a instrumentalização mimética, para, através da indução de emoçôes e sentimentos, provocar comportamentos previsíveis. Essa maneira linguística de operar a política é própria do espetáculo. A política torna-se um espetáculo, eivada pelo uso propagandístico da linguagem. Há que se sublinhar o substrato violento que alimenta esse tipo de linguagem e, como consequência, a espetacularização da política. A deriva espetacular que as democracias tomaram, em nossa contemporaneidade, transcorre paralela à hegemonia do comportamento da massificação mimética, nas outras esferas do social.

O medo é um dos indutores miméticos nos regimes autoritários; através dele, impóem o desenvolvimento imitativo de identidades e demandas como camuflagem para sobrevivência. Nas atuais democracias, não existe o medo dos regimes totalitários, mas isso não significa que nelas não se estimulem muitos tipos de medo, para provocar nos indivíduos atitudes de assimilação imitativa. Por exemplo, a produção comercial das identidades exige que os indivíduos existam, a partir de identificaçóes coletivas massificadas. Quanto mais fechadas forem as identidades, maior será a intensificação mimética exigida para ser aceito no grupo. $\mathrm{O}$ medo de náo ser aceito no grupo induz os indivíduos a assumirem identidades fechadas (nacionalismos, racismos, machismos, tribos urbanas, fanatismos religiosos, perfil profissional, modas...).

As identidades produzem formas de subjetivação e nelas os sujeitos são induzidos a valorizar sua liberdade pessoal, em função dos símbolos identitários, por medo de náo serem aceitos ou integrados no grupo social. 
Em um mundo plural como o nosso, inclusive a diversificação das identidades tornou-se uma técnica de produção de comportamentos. É possível induzir estrategicamente modas, ideias, comportamentos, estilos e, no fim, capturálos sob a propaganda indutora. $\mathrm{O}$ medo de não ser aceito no grupo induz a imitação dos padróes identitários desse grupo. Outros muitos medos são suscitados cotidianamente, para excitar atitudes de seguimento dócil a pautas propagandísticas, como, por exemplo, a lucrativa indústria dos seguros, a qual se alimenta da propaganda da insegurança. Quanto mais inseguras as pessoas se sentirem, mais seguros comprarão.

Os recursos ao medo para induzir comportamentos miméticos amplamente utilizados também pelas sociedades de mercado não estão ausentes na política atual das nossas democracias. O medo é uma tecnologia cotidianamente empregada pelas táticas políticas para provocar na população a aceitação de projetos de governo; para tanto, provocam-se medos estratégicos, como o medo de quebrar o caixa da Previdência, medo do desemprego, medo à reação dos mercados, medo aos estrangeiros etc. São medos muitas vezes hipertrofiados ou até inventados, que servem, a modo de tecnologias políticas, para induzir a aceitação social de projetos políticos salvacionistas desses temores. O medo leva ao seguimento ou eleição de um líder, sob a imagem de um "salvador da pátria" dos muitos perigos difusos que nos ameaçam. A aceitação de determinadas políticas de governo é favorecida, se as pessoas tiverem previamente interiorizado o medo e se a propaganda embrulha as políticas de governo como remédio para os medos.

Ademais, o medo também é utilizado constantemente para projetar no Outro, no estranho, no estrangeiro, os males difusos e variados que nos atingem, e, com isso, se constrói uma atitude de medo do diferente, que de imediato é compensada pela oferta de alternativas políticas para acabar com essa ameaça, expulsando ou até eliminando estrangeiros ou diferentes. Poderíamos alongar-nos, expondo exemplos de utilização do medo como recurso para induzir comportamentos miméticos na política atual. O dito é suficiente para ilustrar a tese de que, mesmo nas democracias, não estamos a salvo da propaganda amedrontadora que produz subjetividades docilizadas.

No limite, a indução mimética dos comportamentos políticos desemboca no espetáculo. Uma política transformada em espetáculo é consequência da massificação comportamental que reage mimeticamente a modelos de induçấo comportamental. Nessa modalidade de mimetismo, a linguagem vai aprimorando seu requinte de violência semântica e, como 
consequência, aprofunda o distanciamento do princípio sobre o qual se originou a política e a democracia, qual seja, o poder persuasivo da linguagem, um poder não violento, que age a partir da verdade exposta publicamente para o debate aberto.

\section{I}

Apresentada a análise crítica, é conveniente desenhar algumas linhas de fuga aos dispositivos de assujeitamento, que haverão de vir pelos pontos de resistência das novas formas de subjetivação. Isso exige a constituição de formasde-vida capazes de se contrapor aos dispositivos de indução de condutas, pela potência de constituir o próprio modo de ser além da massificação midiática.

Uma das linhas de fuga dessa deriva espetacular da política poderia estar, entre outras possibilidades, na própria potencialidade do mimetismo humano. A mimese não se restringe só à mera imitação assimiladora, todavia, contém também a potencialidade de criação imitativa. No ato de imitar é possível criar algo novo. A rigor, toda imitação produz igualmente uma inovação, por menor que seja. Os comportamentos massificados se apresentam como uma massa dócil para o controle social. Contudo, a mimese pode produzir formas imprevistas de reação em massa. Inclusive a própria reação massificada pode tornar-se o reverso de si mesma, quando sujeitos conscientes conseguem introduzir o questionamento do contraditório, no interior da massificação. Se olharmos como se estão processando as grandes mobilizaçóes políticas do século XXI, encontramos em todas elas sinais de direcionamento mimético das tendências, porém, as formas de resistência também utilizam a potência mimética, através da disseminação de comportamentos resistentes. É verdade que o limiar entre resistência e gerenciamento das reaçôes miméticas em grande escala é tão sutil, que, em muitos casos, eles se mesclam de maneira difusa e de difícil discernimento. Entretanto, salienta Agamben: "O espetáculo contem ainda algo como uma possibilidade positiva, que se trata de usar contra ele." (AGAMBEN, 2015, p. 80).

Neste ponto, cabe destacar as posiçôes de Aristóteles e Benjamin a respeito da dimensão criativa da mimese humana. Benjamin percebe que, na imitação das semelhanças, há uma dimensão criativa do semelhante, que só o ser humano tem. As semelhanças produzidas nunca são iguais, nem permanecem as mesmas. Benjamin propóe diferenciar entre semelhante e idêntico (BENJAMIN, 1994, p. 108). O idêntico nega a possibilidade da 
diferença, encerrando a imitação numa identificação fechada como cópia do que se pretende imitar. $\mathrm{O}$ idêntico anula a exterioridade do diferente, por isso, o semelhante nunca é idêntico. A mimese, enquanto faculdade humana, produz a semelhança, porque nela há também diferença.

Um exemplo que Benjamin destaca é o aprendizado da linguagem humana. A linguagem é apreendida através de um alto componente de imitação. A criança aprende pela imitação, porém, imita sempre criando a diferença no ato de imitar. $\mathrm{O}$ vetor da diferenciação é tão relevante na mimese que, segundo Benjamin, inclusive o modo de imitar e as coisas que se imitam mudam, ao longo da história. "Com o passo dos séculos, a energia mimética, e com ela o dom da apreensão mimética, abandonou certos espaços talvez ocupando outros." (BENJAMIN, 1994, p. 109). Para Benjamin, nem as formas da mimese nem as coisas a imitar permanecem as mesmas, no decorrer dos tempos, por isso, a mimese humana contém a potência da diferença na ação imitativa.

A mimese, como parte da própria condição humana, foi trazida para dentro das disputas de poder contemporâneas. Isso significa que, como todo o humano, nenhuma estratégia de poder consegue direcioná-la de modo absoluto, detectando, nas brechas dessa tensão, possibilidades de resistências alternativas. Por tudo isso, poderia se pensar a condição paradoxal da ação mimética como um escopo da categoria da profanação proposta por Agamben. A potência criativa da mimese é capaz de desenvolver outro tipo de ação política, que, desconstruindo a aparente aura de sacralidade midiática que oculta a verdade nas aparências, possa conferir para as coisas um valor de uso, através do qual as pessoas consigam reconduzi-las, para além das aparências, a seu modo de existência cotidiana.

Nesse caso, a própria potência mimética contém a capacidade de profanar os dispositivos que instrumentalizam a mimese como tecnologia para controlar os comportamentos. Profanar os dispositivos miméticos seria devolver à mimese a capacidade criativa de produzir o diferente. No caso que estamos analisando, profanar a propaganda política poderia significar devolver à linguagem a capacidade de impulsionar a consciência crítica que foi apagada dela. Uma última referência textual a Agamben; "Os sonhos e os desejos não realizados da humanidade são, antes, os membros pacientes da ressurreição, sempre a ponto de despertar no dia final. E não dormem fechados em preciosos mausoléus, mas estão pregados, como astros vivos, ao céu remotíssimo da linguagem..." (AGAMBEN, 2012, p. 67). Nenhum 
problema complexo se resolve com soluçóes simples, pelo que a profanação da propaganda mimética envolve, também, a possibilidade de criar formas-devida capazes do uso diferenciado da linguagem como ação política.

RUIZ, C. M. M. B. Violated language and human mimesis in spectacular democracies. interlocutions with Giorgio Agamben. Trans/form/açāo, Marília, v. 44, n. 3, p. 19-44, Jul./Set., 2021.

\begin{abstract}
Abtract: It is urgent that we deepen our critical analysis of the spectacular drift of current democracies. To contribute to this objective, in this essay we will analyze some aspects of Agamben's research on spectacular democracy. In a second point we will develop an analysis of the language that, in the origin of politics, in ancient Greece, which proposed to create a new model of power based on the conviction of truth, and how this language later slid into instrumental techniques of truth in politics. In a third moment we will present the links of human mimesis with the spectacular drift of language in contemporary democracies.
\end{abstract}

Keywords: Spectacular democracy. Violence language. Mass subjectivities. Mimesis. G. Agamben.

\title{
REFERÊNCIAS
}

ADORNO, T.; HORKHEIMER M. Dialética do esclarecimento. Sáo Paulo: Jorge Zahar, 2006.

ADORNO, T.; HORKHEIMER M. Minima Moralia. Reflexóes a partir da vida lesada. São Paulo: Autêntica, 2008.

AGAMBEN, G. Sui limiti della Violenza. Nuovi Argomenti, n. 17, p. 154-174, 1970.

AGAMBEN, G. Il regno e la Gloria. Per una genealogia teologica dell'a economia e del governo. Homo Sacer II, 2. Veneza: Neri Pozza, 2007.

AGAMBEN, G. O reino e a glória. Uma genealogia da economia e do governo. Homo Sacer II, 2. São Paulo: Boitempo, 2011a.

AGAMBEN, G. Introductory note on the concept of Democracy. In: ALLEN, A. (org.) Democracy in what state? New York: Columbia Unversity Press, 2011b. p. 1-5.

AGAMBEN, G. Ideia da prosa. Rio de Janeiro: Autêntica, 2012.

AGAMBEN, G. Meios sem fim: notas sobre a política. São Paulo: Autêntica, 2015.

ARENDT, H. Crises da República. São Paulo: Perspectiva, 2010. 
ASSMANN, S. Da teologia política à teologia econômica: entrevista com Giorgio Agamben. Revista internacional interdisciplinar - INTHERtesis, Florianópolis, v. 2, n. 2, p. 1-11, jan./jul. 2004.

BENJAMIN, W. Magia e Técnica, Arte e Política: ensaios sobre literatura e história da cultura. São Paulo: Brasiliense, 1994.

BERRY, G. L'Hyperpuissance de l'Informatique. Algorithmes, Données, Machines, Réseaux. Paris: Odiel Jacob, 2017.

CAILLOIS, R. Le mythe et l'homme. Paris: Gallimard, 2002.

DEBORD, G. La sociéte du espectacle. Paris: Buchet-Castel, 1967.

DELEUZE, G.; GUATTARI, F. Capitalismo e esquizofrenia. Mil Platôs. v. 1. Rio de Janeiro: Editora 34. 2011.

FOUCAULT, M. Em defesa da sociedade. São Paulo: Martins Fontes, 2008.

FRÜCHTL, J. Mimesis - Konstellation eines Zentralbegriffs bei Adorno. S.1.: Konigshaus und Neumann, 1986.

GAGNEBIN, J. M. Do conceito de mímesis no pensamento de Adorno e Benjamin. Perspectivas. São Paulo, v. 16, 1993.

GEBAUER, G; WULF, C. Mimese na Cultura. São Paulo: Annablume, 2004.

MACGOVERN, M. The Dilemma of Democracy: Collusion and the State of Exception. Studies in Social Justice, v. 5, n. 2, p. 213-230, 2011.

MAUSS, M.; HUBERT, H. Esquisse de une Théorie générale de Ia Magie. L’Année Sociologique. 1902-1903. Disponível on-line em: http://classiques.uqac.ca/classiques/ mauss_marcel/socio_et_anthropo/1_esquisse_magie/esquisse_magie.html Acesso em: 14 ago. 2019.

MULLEN, G. Adorno on Politics After Auschwitz. Lanham: Lexington Books, 2016.

MURRAY, A.; WHYTE, J. (ed.). The Agamben Dictionary. Edimburgh: Edimburgh University Press, 2011.

MUrRaY, P. (ed.). Plato on Poetry. New York; Melbourne: Cambridge University Press, 1966.

PLATÃO. A República. Oeuvres complètes. Trad. fr. par L. Robin. Paris: Bibliothèque de la Pléiade, 1950a.

PLATÃO. Politeia, III. Oeuvres complètes. Trad. fr. par L. Robin. Paris: Bibliothèque de la Pléiade, 1950b.

PLATÃO. Sofista. Oeuvres complètes. Trad. fr. par L. Robin. Paris: Bibliothèque de la Pléiade, 1950c. 
ROSS, D. Democracy, authority, narcissism: from Agamben to Stiegler. Contretemps, v. 6, p. 74-85, jan. 2006.

RUIZ, C. M. M. B. La mimesis humana. La condición paradójica de la acción imitativa. Saarbrücken: OmniScriptum, 2016.

SADE, Marquês de. Filosofia na Alcova. São Paulo: Iluminuras, 2013.

SCHMITT, C. Versfassungslehre. Berlin: Dunker \& Humbolt, 1938.

TIBURI, M. Crítica da razáo e mímesis no pensamento de Theodor Adorno. Porto Alegre: EDIPUCRS, 1995.

ZARKA, Y. Figures du pouvoir. Études de philosophie politique de Machiavel à Foucault. Paris: Presses Universitaires de France, 2001. 